\title{
Revision of Euspilotus, subgenus Platysaprinus, with description of two new species (Coleoptera: Histeridae)
}

\author{
Tomáš LACKNER ${ }^{1)}$ \& Gerardo ARRIAGADA ${ }^{2)}$ \\ 1) Bavarian State Collection of Zoology, Münchhausenstraße 21, DE-81247 Munich, Germany; e-mail: tomaslackner@me.com \\ ${ }^{2)}$ Colaborador Área Entomología, Museo Nacional de Historia Natural, Casilla 787, Correo Central, Santiago, Chile; e-mail: euspilotus@gmail.com
}

\author{
Accepted: \\ $14^{\text {th }}$ April 2020 \\ Published online: \\ $23^{\text {rd }}$ April 2020
}

\begin{abstract}
The Neotropical subgenus Platysaprinus Bickhardt, 1916 of the genus Euspilotus Lewis, 1907 is revised, keyed and figured. Saprinus myrmecophilus Bickhardt, 1910, is newly transferred into genus Euspilotus Lewis, 1907, subgenus Platysaprinus Bickhardt, 1916. Euspilotus (Platysaprinus) carinipennis (Desbordes, 1924), is newly synonymized with Euspilotus (Platysaprinus) myrmecophilus (Bickhardt, 1910) syn. nov., based on examination of the type material. Two new species: Euspilotus (Platysaprinus) ferreri sp. nov. from Brazil (Minas Gerais, Mato Grosso and Rio de Janeiro) and Euspilotus (Platysaprinus) vazdemelloi sp. nov. from Brazil (Mato Grosso) are described. Euspilotus (Platysaprinus) latimanus (Schmidt, 1890) is newly reported from Argentina (Misiones), Paraguay (Amambay) and Bolivia. Lectotypes and paralectotypes of Saprinus latimanus Schmidt, 1890 are designated.
\end{abstract}

Key words. Coleoptera, Histeridae, Saprininae, Euspilotus, Platysaprinus, revision, new species, Neotropical Region

\section{Introduction}

Euspilotus Lewis, 1907 is a species-rich genus distributed primarily in the Nearctic and, especially, in the Neotropical realms, where it exceeds any other saprinine genus in terms of species diversity (LACKNER 2010). Currently it contains four subgenera and 83 species (MAZUR 2011, DÉGALLIER et al. 2012,ARRIAGADA 2015,ARRIAGADA et al. 2019); multiple new species are awaiting descriptions (Arriagada, unpublished data). Most of the Euspilotus species are typical generalist predators found on carcasses or dung of various mammals, with several species found also inside bird or rodent nests (LACKNER 2014). Although Euspilotus is divided into four subgenera, the exact definitions of these are unclear and there are no clear synapomorphies defining them. LACKNER (2014) in his morphology-based phylogenetic analysis of the subfamily revealed a non-monophyletic Euspilotus with large variation found in the sensory structures of the antenna; the on-going molecular analysis of the subfamily confirms the non-monophyletic origin of the genus (Lackner et al., unpublished data).

The subgenus Platysaprinus Bickhardt, 1916 was originally erected as a separate monotypic genus, with Saprinus latimanus Schmidt, 1890 as its type species (BICKHARDT 1916). Platysaprinus was treated as a subgenus of Euspilotus by MAZUR (1984: 72), with all subsequent works and catalogues following suit.

BICKHARDT (1916), when defining his new genus Platysaprinus, pointed out an enlarged antennal scape, deeply impressed, carinate and almost complete first dorsal elytral stria, and rather short legs with dilated tibiae, among other characteristics typical for the members of either Saprinus Erichson, 1834 or Euspilotus. Although SchmidT (1890) did not provide any biological data for his Saprinus latimanus, BiCKHARDT (1916), based on the triangularly shaped and thickened antennal scape as well as broadened tibiae of this species, deduced that 'die Angehörigen der Gattung leben bei Termiten' - hinting at the possible termitophily of the taxon members. In this contribution we aim to provide synapomorphies of the subgenus Platysaprinus, discuss its morphology and describe two new Neotropical species.

\section{Material and methods}

Dry-mounted specimens were relaxed in warm water for several hours. After removal from the original cards, they 
were side-mounted on a triangular point and examined under a Nikon 102 binocular microscope with diffuse light. Male genitalia, mouthparts and antennae were first macerated in $10 \% \mathrm{KOH}$ solution for about three hours, afterwards cleared in $80 \%$ alcohol and macerated in lactic acid with fuchsine, incubated at $60{ }^{\circ} \mathrm{C}$ for another 30 minutes, and subsequently cleared in $80 \%$ alcohol and then observed in $\alpha$-terpineol in a small glass dish. Digital photographs of male genitalia, antennae and mouthparts were taken with a Nikon 4500 Coolpix camera and edited in Adobe Photoshop CS5. Based on the photographs, or direct observations, the genitalia, mouthparts and antenna were drawn using a light-box Hakuba klv-7000 (Tokyo, Japan). Habitus photographs were made by F. Slamka (Bratislava, Slovakia). SEM micrographs were taken with a JSM 6301F scanning microscope at the laboratory of Faculty of Agriculture, Hokkaido University, Sapporo, Japan. The map used in the present paper was downloaded from the FreeVectorMaps project (www.freevectormaps.com) and edited in Adobe Illustrator and Adobe Photoshop.

Specimens were measured with an ocular micrometer. Body part terminology follows that of ÔHARA (1994) and LACKNER (2010), and the following abbreviations of morphological measurements are used:

APW width between anterior angles of pronotum

EL length of elytron along elytral suture

EW maximum width between outer margins of elytra

PEL length between anterior angles of pronotum and apices of elytra

PPW width between posterior angles of pronotum

Labels of type specimens were recorded verbatim in single quotations; a single vertical bar separates rows within a label, and a double vertical bar separates individual labels. Additional remarks are given in square brackets.

Specimens examined in this study are deposited in the following collections:

CEMT Collection Entomological, Universidad Federal de Mato Grosso, Brazil, Mato Grosso, Cuiabá (F. Z. Vaz de Mello);

CND private collection of Nicolas Dégallier (Paris, France);

CSCA California State Collection of Arthropods, Sacramento, CA, USA (A.K. Tishechkin);

CTLA private collection of Tomáš Lackner (temporarily housed in Zoologische Staatssammlung München, Munich, Germany);

CVMD private collection of Victor Manuel Diéguez Martinez (Santiago de Chile, Chile);

MACN Museo Argentino de Ciencias Naturales "Bernardino Rivadavia" Buenos Aires Argentina (A. Roig);

MFNB Museum für Naturkunde, Berlin, Germany (B. Jäger);

MNHN Muséum National d'Histoire Naturelle, Paris, France (A. Taghavian);

MNHNC Museo Nacional de Historia Natural, Santiago, Chile (M. Elgueta);

MSNG Museo Civico di Storia Naturale 'Giacomo Doria', Genova, Italy (M. Tavano);

NMPC National Museum, Prague, Czech Republic (J. Hájek).

\section{Taxonomy}

\section{Genus Euspilotus Lewis, 1907}

Euspilotus: MAZUR (2011): 189 (catalogue); LACKNER et al. (2015): 113 (catalogue).

Note. Complete list of synonymies and literature references of this taxon are given in LACKNER (2010: 105) and the rea- der is referred to them there. For the sake of completeness we list the references published after LACKNER (2010).

\section{Subgenus Platysaprinus Bickhardt, 1916}

Platysaprinus: BicKHARDT (1914): 306 (nomen nudum).

Platysaprinus Bickhardt, 1916: 106 (original description). BLACKWELDER (1944): 180 (catalogue).

Euspilotus (Platysaprinus): MAZUR (1984): 72 (catalogue); MAZUR (1997): 239 (catalogue); MAZur (2011): 192 (catalogue).

Type species. Saprinus latimanus Schmidt, 1890 by original designation.

Diagnosis. Dark-brown, elongate-oval to broadly-oval non-metallic Saprininae beetles of small to moderate size, with reddish to brown-red body appendages. Frontal stria widely interrupted and prolonged onto clypeus. Lacinial uncus in at least one species (E. (P.) latimanus)) present; antennal scape (triangularly) dilated. Lateral pronotal stria complete and carinate in most species. Dorsal elytral striae 1-4 present, sutural elytral stria present or vaguely impressed to absent; elytral disc in most species with dense punctures. Apical elytral stria shortened to absent. Flanks of pygidium in one species keel-like. Prosternal process compressed, usually keel-like, apical prosternal stria present, in most cases connecting large prosternal foveae; both sets of prosternal striae usually present. Tibiae dilated and rather short. Apex of sternite VIII of male genitalia with a brush of tiny setae; tergite VIII usually outwardly arcuate; apex of spiculum gastrale usually gradually broadly dilated medio-apically. Aedeagus with rather short phallobase, in most species narrowing apically with pointed apex.

Differential diagnosis. Members of Platysaprinus differ from the rest of the Euspilotus chiefly in the dilated tibiae, especially the protibiae. Their non-metallic, entirely punctate upper body surface (with the exception of $E$. $(P$.) ferreri)), or non-maculate elytra can also distinguish them from their Neotropical congeners. Most, if not all members of Euspilotus from the South American continent are found on carrion, occasionally also in dung. On the contrary, Platysaprinus members are, as far as it is known, inquilines of ants. Our current state of knowledge and the amount of undescribed South American Euspilotus prevent us from providing a more detailed differential diagnosis for the subgenus.

Biology. Euspilotus (Platysaprinus) myrmecophilus as well as Euspilotus (Platysaprinus) latimanus were collected in the nests of fungus growing ants of the genus Acromyrmex Mayr, 1865 (Hymenoptera: Formicidae: Myrmicinae) (LACKNER 2014 and the references therein). The two newly described species are of unknown biology; one of them was collected using flight interception traps (FIT).

Distribution. Argentina: Misiones; Bolivia; Brazil: Federal District, Paraná, Rio Grande do Sul, Mato Grosso, Minas Gerais, São Paulo; Paraguay: Amambay; Uruguay.

\section{Key to species}

1(2) Large species ( $\mathrm{PEL}=3.55-5.50 \mathrm{~mm})$, first dorsal elytral stria keel-like, costate (Fig. 1), lateral sides 
of pygidium costate (Fig. 8). Argentina: Misiones; Bolivia; Brazil: Federal District, Mato Grosso, Minas Gerais, São Paulo; Paraguay: Amambay). Euspilotus (P.) latimanus (Schmidt, 1890)

2(1) Smaller species $(\mathrm{PEL}=2.10-4.00 \mathrm{~mm})$, first dorsal elytral stria not keel-like (Fig. 23), lateral sides of pygidium not costate.

3(4) Elytra on basal half impunctate (Fig. 34). Brazil: Minas Gerais, Mato Grosso and Rio de Janeiro.

Euspilotus (P.) ferreri sp. nov.

4(3) Entire elytra densely punctate (Figs 23, 45).

5(6) Body elongate oval; dorsal elytral striae 3-4 abbreviated basally (Fig. 45), smaller species ( $\mathrm{PEL}=2.10$ 2.30). Brazil: Mato Grosso.

Euspilotus $(P$.$) vazdemelloi sp. nov.$

6(5) Body broadly oval; dorsal elytral striae 3-4 almost reach elytral base (Fig. 23), larger species ( $\mathrm{PEL}=3.00$ $4.00 \mathrm{~mm}$ ). Argentina, Brazil, and Uruguay.

.... Euspilotus (P.) myrmecophilus (Bickhardt, 1910)

\section{Euspilotus (Platysaprinus) latimanus \\ (Schmidt, 1890)}

(Figs 1-22, 56)

Saprinus latimanus Schmidt, 1890: 50 (original description). BLACKWELDER (1944): 179 (catalogue).

Platysaprinus latimanus: BicKHARDT (1916): 106, table 5, Fig. 36 (catalogue); BLACKWELder (1944): 180 (catalogue).

Euspilotus (Platysaprinus) latimanus: MAzur (1984): 72 (catalogue); MAzur (1997): 239 (catalogue); MAzUr (2011): 193 (catalogue).

Type locality. Original type locality 'Brasilia (Matto grosso)' specified here by lectotype designation to: Brazil: Mato Grosso: Rio Madeira.

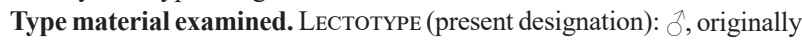

pinned, glued onto a rectangular mounting card, right mid-leg broken off, glued to the mounting card next to the specimen, genitalia extracted and placed into a small vial under the specimen, 'Matto Grosso | Rio Madeira [written] || Type [brick-red, printed label] || SYNTYPUS | Saprinus | latimanus Schmidt, 1890 | labeled by MNHUB 2004 [red label, printed] || Lectotypus $\widehat{\partial} \mid$ Euspilotus | (Platysaprinus) | latimanus (Schm.)| Det. G. Arriagada 2004 [printed-written]'(MFNB). PARALECTOTYPes: + , pinned, 'Brazil | Natterer [written] || latimanus | Type Schm. [written] || Type [brick-red, printed label] || coll. J. Schmidt [printed] || Platysaprinus | latimanus | Schm. [written] || SYNTYPUS | Saprinus | latimanus Schmidt, 1890 | labeled by MNHUB 2004 [red label, printed] || Paralectotypus $q$ | Euspilotus | (Platysaprinus) | latimanus (Schm.) | Det. G. Arriagada 2004 [printed-written]' (MFNB); + , originally pinned, glued on the rectangular mounting card, most legs either entirely or partly missing, 'Matto Grosso | Rio Madeira [written] || Type [brick-red, printed label] || SYNTYPUS | Saprinus | latimanus Schmidt, 1890 | labelled by MNHUB 2004 [red label, printed] || Paralectotypus + | Euspilotus | (Platysaprinus) | latimanus (Schm.) | Det. G. Arriagada 2004 [printed-written]' (MFNB).

Additional material examined: BRAZIL: FEDERAL DISTRICT: Brasilia, xii.1987, 1 §, 2 spec., F. Vaz de Mello lgt., FIT (CND); Brasilia, 1547'S, 4755’W, x.1999, 1 spec (at light), N. Dégallier lgt. (CSCA). São Paulo: São Paulo, 6 2 + 0 , Mráz lgt. (NMPC, $3 \precsim$ in MSNG); São Paulo, Ypiranga, 10.iii.[18]84, 1 §ै, collector unknown (MFNB). Mato Grosso: Municipalidade Cuiabá, Fazenda Mutuca, $15.3145^{\circ} \mathrm{S}, 55.9703^{\circ} \mathrm{W}$, 30.xii.2008, 1 spec. (flight intercept trap), F.H. Gava \& J.R. Rocha lgt. (CSCA); Municipalidade Diamantino, Vale de Solidão, $14^{\circ} 21.63^{\prime} \mathrm{S}$ 56 6.4’ W, 22.xii.2008-26.i.2009, 2 spec. (flight intercept trap), D.C.T. Oliveira lgt. (CSCA); Chapada dos Parecis, Campos de Julio, 30 km N of Ville abandonee d'Uirapuru, Usine Alcomat, $14^{\circ} 16^{\prime} 4^{\prime \prime} \mathrm{S}, 54^{\circ} 14^{\prime} 1^{\prime \prime} \mathrm{W}$, 1.-15.xii.2000, 2 우, A. Foucart lgt. (CND); Chapada dos Parecis, $14^{\circ} 15^{\prime} 50.80^{\prime \prime} \mathrm{S}, 59^{\circ} 14^{\prime} 02.05^{\prime \prime} \mathrm{W}, 1$ spec. (CND); Tangará da Serra, Faz. Aparecida da Serra, $14^{\circ} 21^{\prime} 16^{\prime \prime} \mathrm{S}, 57^{\circ} 44^{\prime} 00^{\prime \prime} \mathrm{W}, 562 \mathrm{~m}$, cerrado, 3.ii.2010, $3 \hat{\jmath}, 1$ spec. (FIT), R.J. Silva lgt. (CVMD). Minas Gerais: Jaboricatu Bes, x.1951, 1 spec., Perreira lgt. (coll. Thérond, MNHN); Parc Natural da Serra do Cipó, 5.x.2004, 2 spec., 5.xii.2004, 1 (CVMD). UNKNOWN STATE: IBGE-JANELA/Q, 7.xi.1987, 1 ㄱ, 1 spec., ZOO 23 (CND). PARAGUAY: AMAMbay: P. N. Cerro Corá, 1.-6.ii.2006, 280 m,
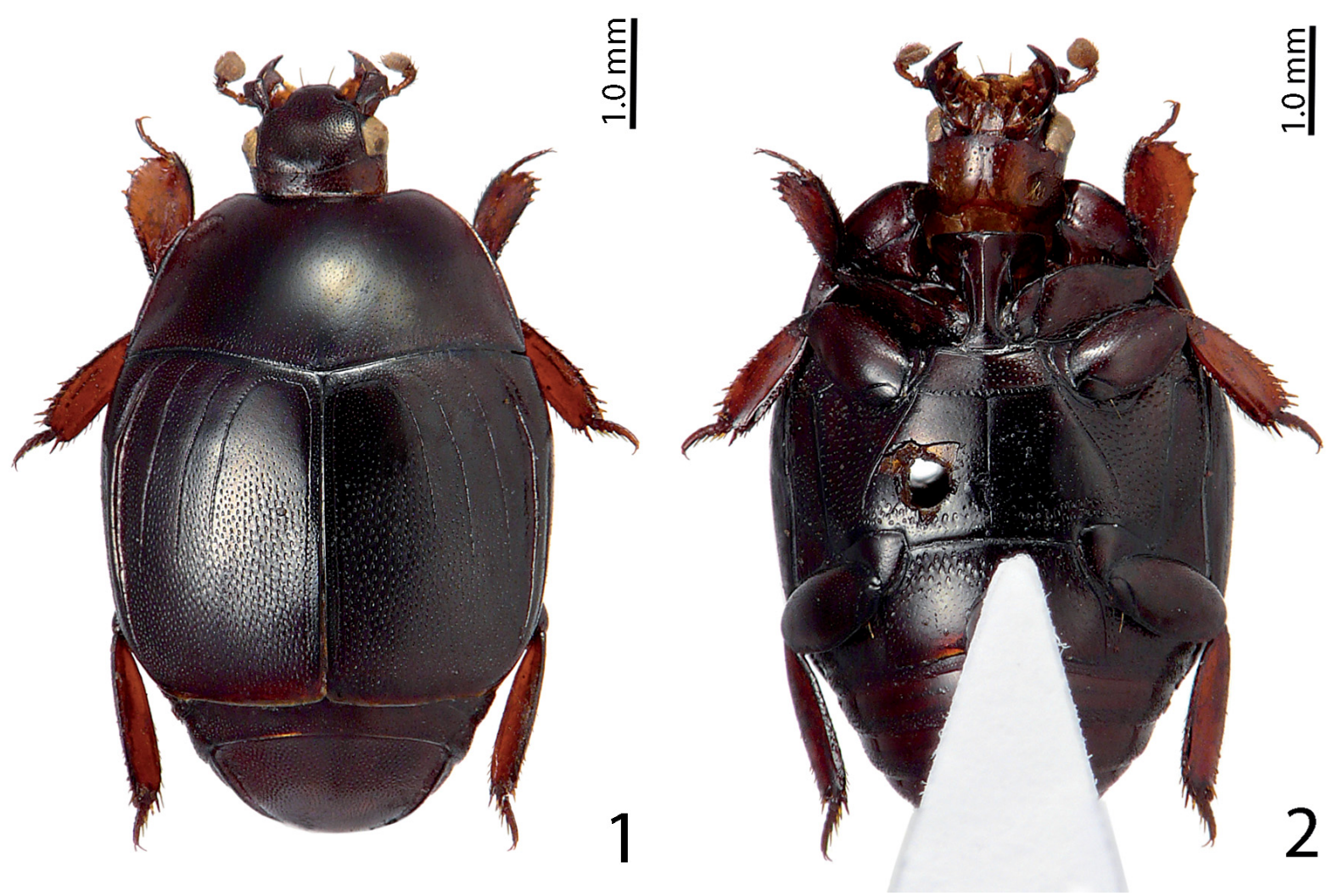

Figs 1-2. Euspilotus (Platysaprinus) latimanus (Schmidt, 1890). 1 - habitus, dorsal view; 2 - ditto, ventral view. 

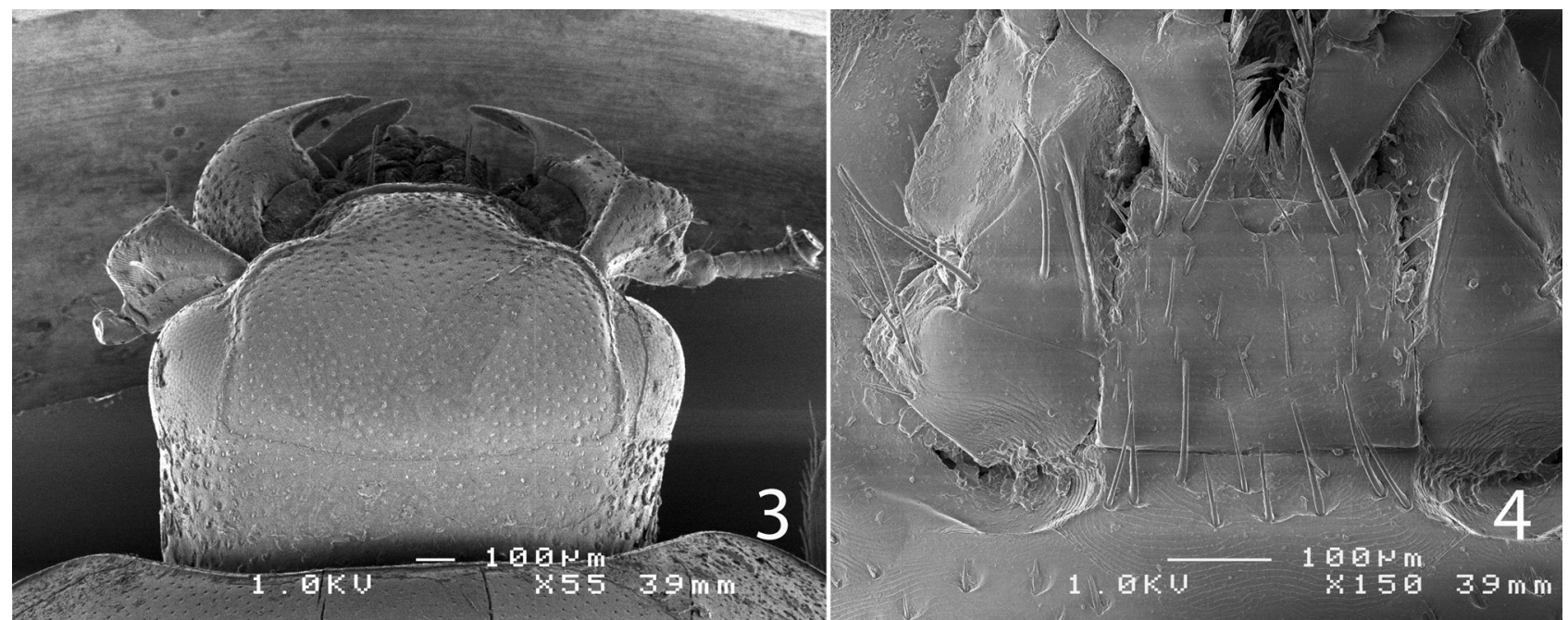

Figs 3-4. Euspilotus (Platysaprinus) latimanus (Schmidt, 1890). 3 - head, dorsal view; 4 - mentum.

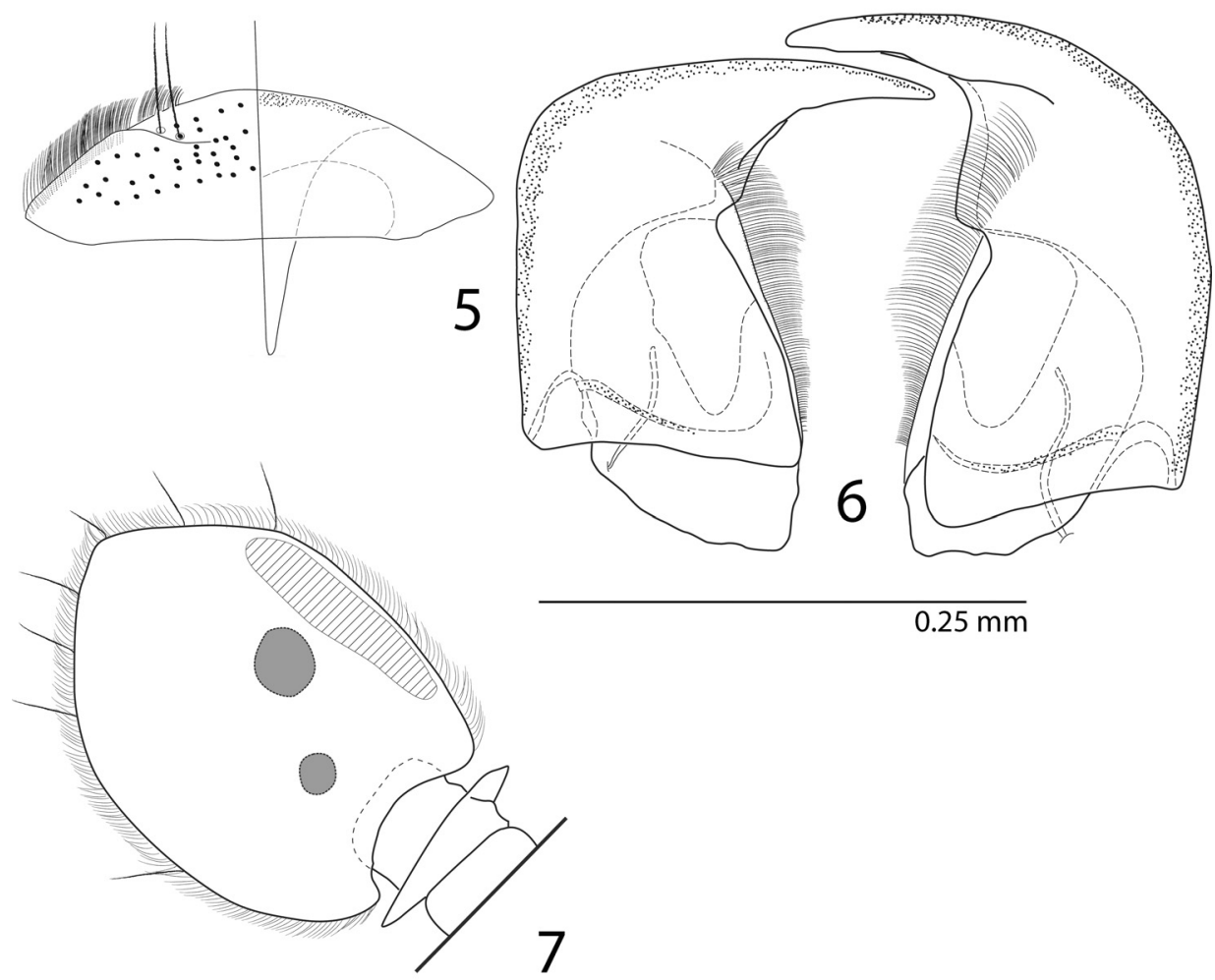

Figs 5-7. Euspilotus (Platysaprinus) latimanus (Schmidt, 1890). 5 - labrum, dorsal view; 6 - mandibles, dorsal view; 7 -antennal club showing sensory structures of the antenna, dorsal view.

22 $38^{\prime} \mathrm{S} 56^{\circ} 01^{\prime} \mathrm{W}, \mathrm{R}$. Barrera lgt. (CVMD). ARGENTINA: Misiones: depto. Concepción, Santa María, xii.1958, 4 đo 2 우, M. Viana lgt. (1 + CTLA; rest of specimens CVMD). BOLIVIA: 'Mojos' [= ? Moxos], 1 spec., N. Holmgren lgt. (NRMS).

Redescription. Body (Figs 1-2). PEL: 3.55-5.50 mm; APW: $1.35-2.20 \mathrm{~mm}$; PPW: 3.30-4.20 mm; EW: 3.65$4.70 \mathrm{~mm}$; EL: 2.55-3.20 mm; broadly oval, slightly depressed dorsally; cuticle dark-brown to black; appendages reddish-brown.

Head. Frons densely punctate, punctures regular, separated by about their own to twice their diameter. Frontal disc (Fig. 3) approximately as broad as long, slightly depressed medio-anteriorly; occipital stria very thin; supra-orbital stria slightly carinate, for short distance prolonged onto punctate and weakly depressed epistoma. Labrum (Fig. 5) with labral pits and setae; mentum (Fig. 4) sub-trapezoid, lateral sides with row of prominent setae; anterior margin with deep notch; lacinial 'hook' (= uncus) present. Mandibles (Fig. 6) dorsally with scattered punctation, punctures becoming larger, shallow and confluent laterally; sub-apical tooth on left mandible absent; mandibular apices pointed. Antennal scape (Fig. 3) thickened, dorsally punctate, on lower third adorned with characteristic single long seta, with single shorter seta dorsally; antennal club (Fig. 7) depressed, densely covered with sensilla sparsely intermingled with erect longer setae; sensory structures 


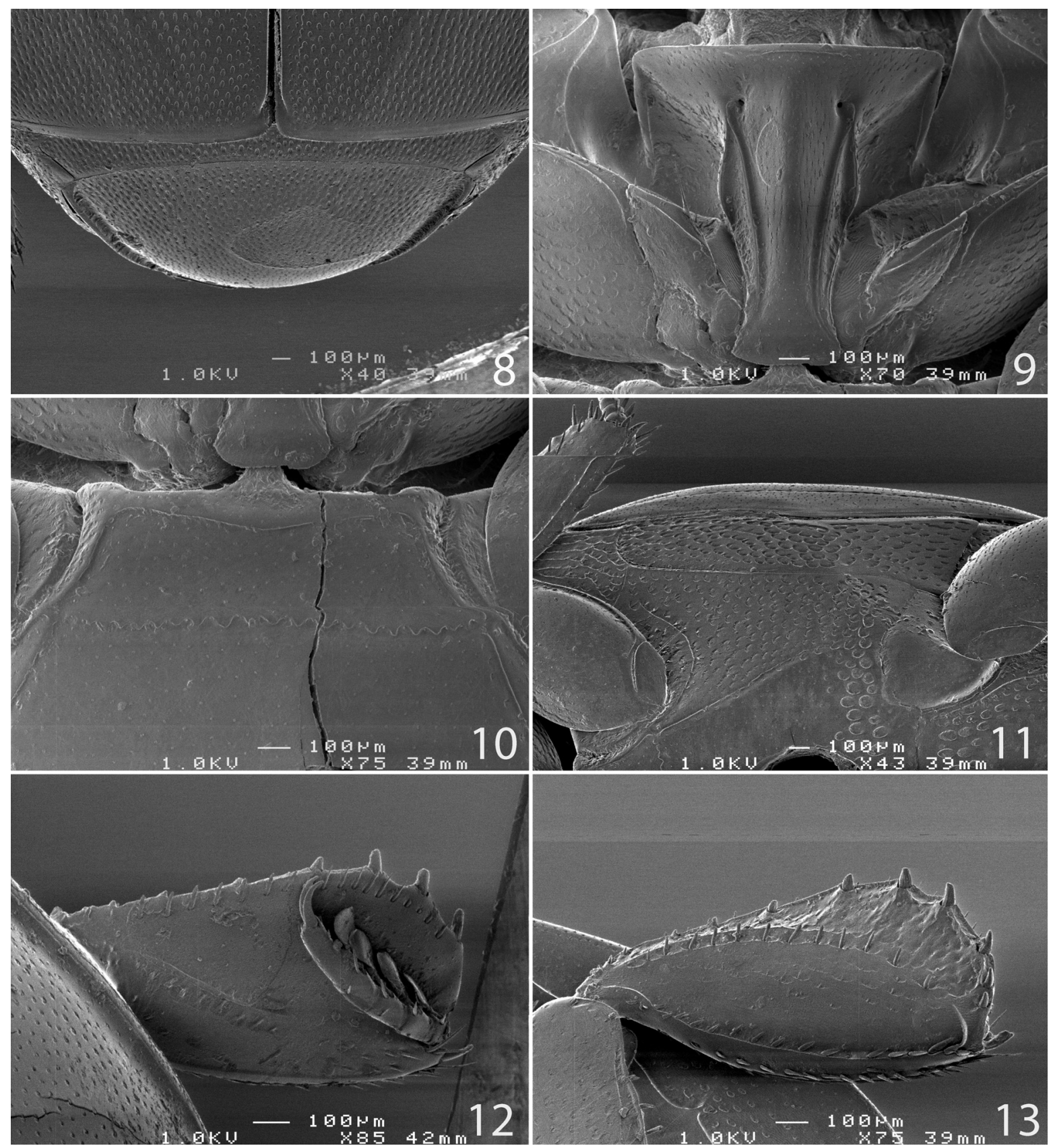

Figs 8-13. Euspilotus (Platysaprinus) latimanus (Schmidt, 1890). 8 - pygidium; 9 - prosternum; 10 - mesoventrite; 11 - lateral disc of metaventrite + metepisternum; 12 - protibia, dorsal view; 13 - ditto, ventral view.

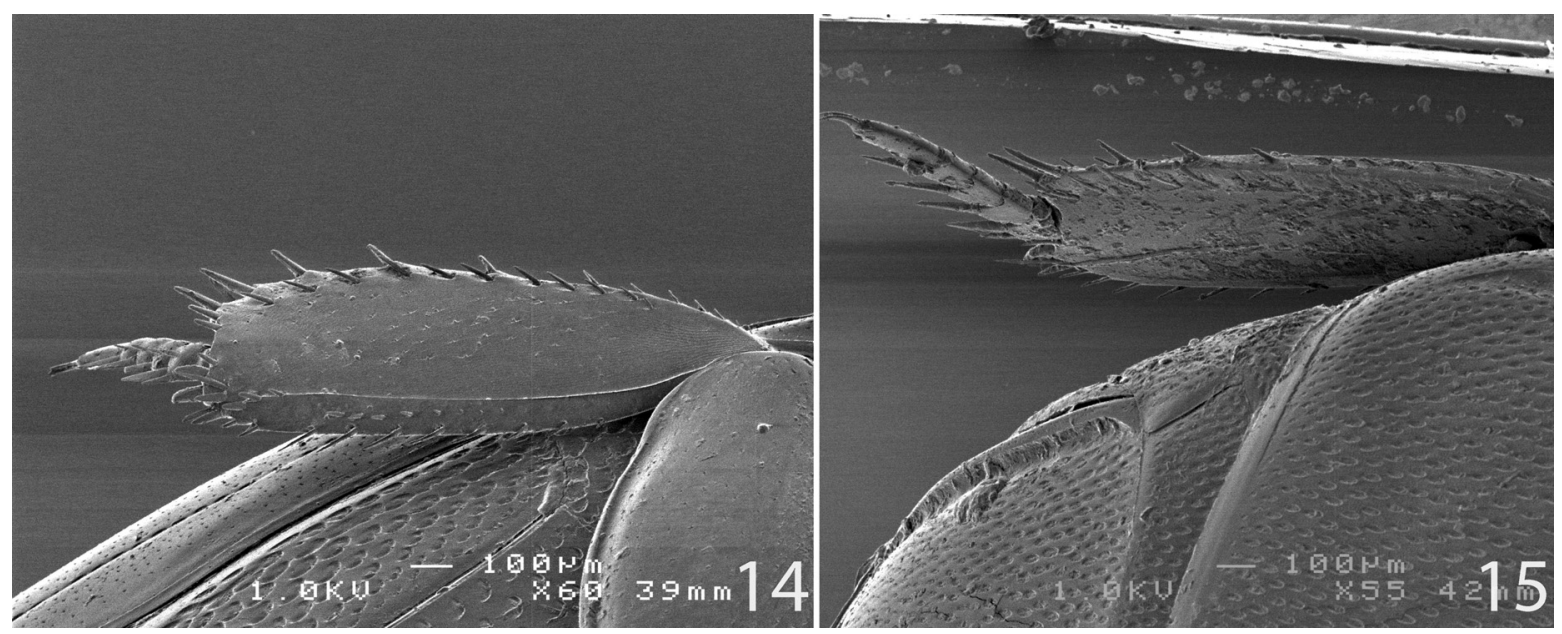

Figs 14-15. Euspilotus (Platysaprinus) latimanus (Schmidt, 1890). 14 - mesotibia, ventral view; 15 - metatibia, dorsal view. 

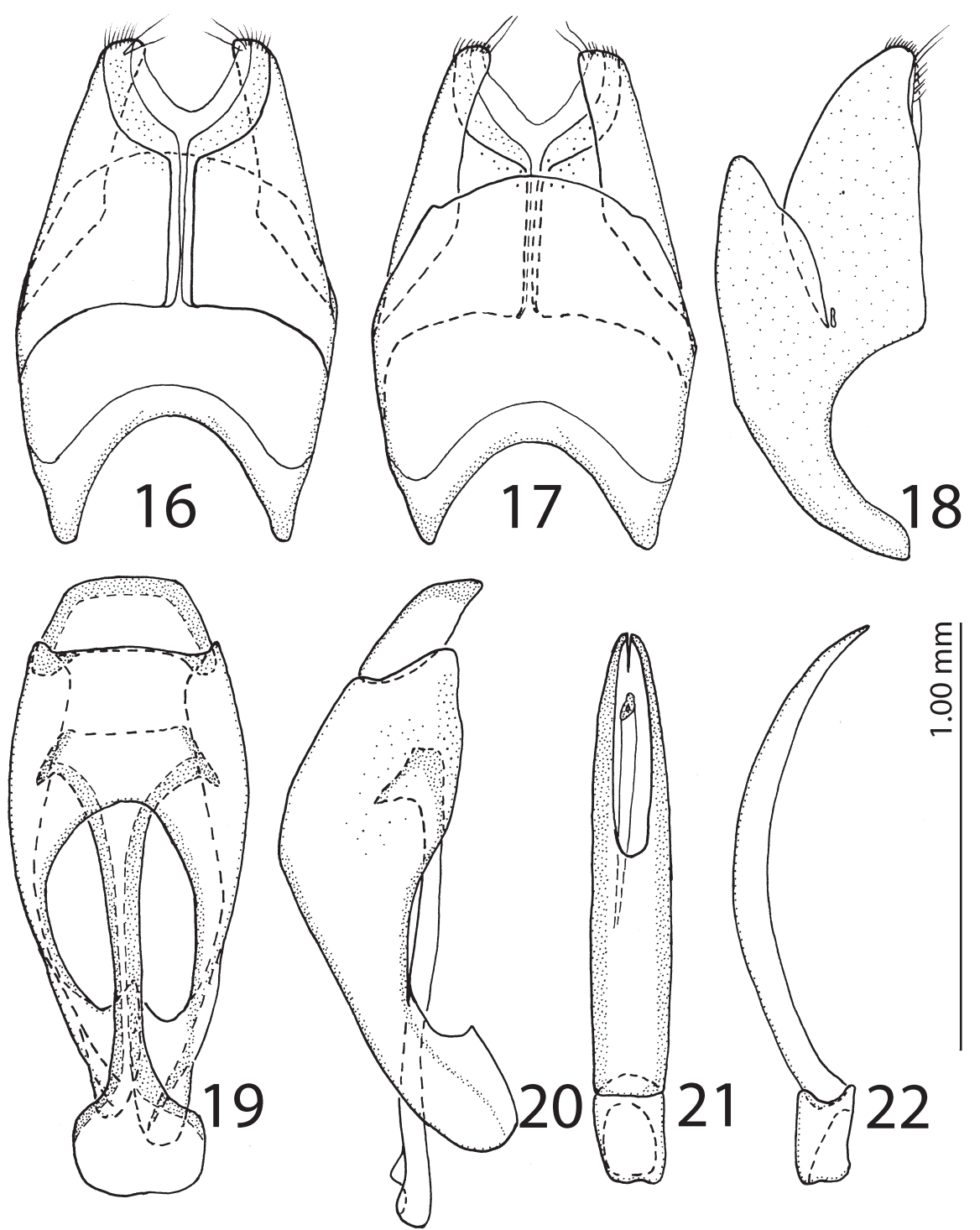

Figs 16-22. Male genitalia of Euspilotus (Platysaprinus) latimanus (Schmidt, 1890). 16 - VIII sternite and tergite, ventral view; 17 - ditto, dorsal view; 18 - ditto, lateral view; 19 - IX and X tergites, dorsal view and IX sternite (spiculum gastrale), ventral view; 20 - IX and X tergites and IX sternite (spiculum gastrale), lateral view; 21 - aedeagus, dorsal view; 22 - ditto, lateral view.

of the antennal club (Fig. 7) ventrally with single round sensory area concealing two ball-like vesicles beneath. Eyes large, well visible from above.

Pronotum. Pronotal sides (Fig. 1) narrowing anteriorly; lateral pronotal stria complete, weakened behind head, costate laterally, not reaching basal pronotal angles, slightly distanced from lateral pronotal margin on basal tenth. Entire pronotal disc covered with fine and rather sparse punctures separated by a distance several times their diameter; punctation becomes somewhat denser and coarser laterally; along pronotal base doubled row of larger and denser punctures present. Pronotal hypomeron asetose.

Elytra. Elytral epipleuron (Fig. 10) with sparse microscopic punctation; marginal epipleural stria fine, complete; marginal elytral stria fine, slightly carinate, slightly prolonged onto elytral base, for short distance continues along elytral apex, apical elytral stria absent otherwise. Humeral elytral stria weakly impressed on basal elytral fourth, indiscernible in several specimens; inner subhumeral stria well impressed, originating near apex of humeral elytral stria, terminating near apex of first dorsal elytral stria and parallel to it; first dorsal elytral stria basally linked with humeral elytral stria, continues as elongate costa almost along its entire length, stopping short of elytral apex; between sutural elytral stria and elytral suture 2-3 rows or minuscule punctures present. Dorsal elytral striae 2-4 slightly surpassing or almost reaching half of elytral length apically, well-impressed, punctate, their basal ends curved inwardly; fourth (occasionally also third) dorsal elytral stria basally connected with almost complete and well-impressed sutural elytral stria that is serrated on its apical half; sutural elytral stria stops short of elytral apex. Elytral disc on basal fourth covered with fine minuscule punctures separated by several times their diameter, approximately near mid-length of elytral disc punctures become distinctly denser and elongate, on apical elytral third to fourth punctures almost confluent, occasionally forming elongate rugae, separated by less than their own 
diameter, interspaces among them with very fine alutaceous microsculpture visible with strong magnification; extreme elytral apex glabrous.

Propygidium covered with very dense punctures similar to those on apical third of elytral disc; pygidium (Fig. 8) on basal half with perhaps even denser punctation; punctures become much sparser and finer on apical pygidial half, extreme pygidial apex only with microscopic punctation. Lateral margins of pygidium elevated, costate.

Prosternum (Fig. 9). Outer lateral costa of prosternum not reaching prosternal process, interrupted by antennal cavity. Prosternal process compressed, keel-like, covered with sparse fine punctures; marginal prosternal stria fine, present along apical prosternal margin. Prosternal process apically with two large and deep prosternal foveae; carinal prosternal striae well impressed, divergent apically, terminating in prosternal foveae; lateral prosternal striae short, costate, apically terminating near prosternal foveae.

Mesoventrite (Fig. 10) approximately three times as broad as long; marginal mesoventral stria fine, complete; disc of mesoventrite with scattered fine punctures, interspaces with microsculpture; meso-metaventral stria complete, undulate.

Metaventrite (Fig. 10) except for basal fifth that bears several rows of rather large shallow and dense punctures entire metaventral disc covered with sparse microscopic punctation, punctures separated several times their diameter. Lateral disc of metaventrite (Fig. 11) with almost confluent shallow punctures; metepisternum with similar, if even denser punctures.

First visible abdominal ventrite. Basal third slightly depressed, bearing several rows of large dense elongate punctures; rest of first visible abdominal ventrite almost impunctate; in and around apical angles larger and dense punctures appear.

Legs. Protibia (Figs 12-13) dilated, outer margin without distinct teeth, only with $8-9$ short denticles diminishing in size proximally; protibial spur rather short, growing out from near tarsal insertion, protarsal groove shallow; protibial stria complete, without another complementary stria next to it; setae of outer row rather short, regularly-spaced. Outer part of posterior surface of protibia (Fig. 13) lacunose; separated from median part by double stria beset with setae; posterior protibial stria complete, with dense setae running along posterior protibial stria; setae form near apex several thickly-set inner-posterior denticles; inner row of setae dense, regular; apical margin with two apical denticles. Mesotibia (Fig. 14) and metatibia (Fig. 15) dilated, with sparse denticles on outer margins.

Male genitalia. Sternite VIII (Figs 16-17) divided medially, apically with tuft of short dense setae and short velum; tergite VIII outwardly arcuate; sternite VIII and tergite VIII fused laterally (Fig. 18). Tergites IX and X (Figs 19-20) typical for the subfamily; spiculum gastrale dilated on both ends (Fig. 19). Aedeagus (Figs 21-22): phallobase markedly short, ratio to parameres 1 : 8; parameres fused approximately on their apical half; aedeagus narrowing and pointed apically.
Differential diagnosis. Differs from the other congeners by the elevated pygidial margins as well as the costate first dorsal elytral stria. This is the largest species of the subgenus.

Distribution. Known from Brazil (Federal District, Mato Grosso, Minas Gerais, São Paulo). Newly recorded from Argentina (Misiones), Paraguay (Amambay) and Bolivia. Biology. Found in nests of Acromyrmex ants (ARRIAGADA 1987).

Remarks. Although SchmidT (1890) did not specify the number of specimens he used for the description of Saprinus latimanus, he gave a size range $(5.50-6.00 \mathrm{~mm})$, which means he must have examined multiple specimens, which are therefore syntypes. The male specimen was chosen as the lectotype to fix the identity of the species.

The Bolivian locality Mojos was not located on the Internet and is therefore depicted with question mark on the distributional map (Fig. 56). It is possibly the province of Moxos, in the department of Beni (Bolivia).

BLACKWELDER (1944) erroneously listed this species twice, once in Saprinus (p. 179) and then in Platysaprinus (p. 180).

\section{Euspilotus (Platysaprinus) myrmecophilus (Bickhardt, 1910)}

(Figs 23-33, 56)

Saprinus myrmecophilus Bickhardt, 1910: 223, Fig. 1 (original description). BLACKWELDER (1944): 179 (catalogue).

Euspilotus myrmecophilus: BICKHARDT (1916): 83 (catalogue); BLACKWELDER (1944): 178 (catalogue).

Saprinus carinipennis Desbordes, 1924: 372 (original description). BLACKWELDER (1944): 179 (catalogue), syn. nov.

Euspilotus (Platysaprinus) carinipennis: ArRIAGAda (1987): 68 (new combination); MAZUR (1997): 239 (catalogue); MAZUR (2011): 193 (catalogue).

Platysaprinus zikani Reichensperger, 1926: 194, Figs 4-5 (original description); BLACKWELDER (1944): 180 (catalogue).

Euspilotus (Platysaprinus) zikani: MAZUR (1984): 72 (catalogue); ArRIAGADA (1987): 68 (synonymy with E. (P.) carinipennis).

Platysaprinus zikani var. daguerrei Bruch, 1931: 390 (original description). BLACKWELDER (1944): 180 (catalogue); ARRIAGADA (1987): 68 (synonymy with E. (P.) carinipennis).

Type localities. Saprinus myrmecophilus: Uruguay: Cerrito near Montevideo; S. carinipennis: Argentina: Misiones: Environs de San Ignacio, Villa Lutelia; Platysaprinus zikani: Brazil: Rio de Janeiro: Campo Bello; P. zikani var. daguerrei: Argentina: Buenos Aires: Rosas.

Type material examined. Saprinus myrmecophilus: HoLOTYPE: $\curvearrowright$, glued onto a tip of a triangular mounting card, four segments of left metatarsus missing, genitalia extracted, disarticulated and placed into a small vial underneath the specimen, 'Montevideo $\mid$ J. Tremoleras [black-margined, printed label] || Saprinus | myrmecophilus | n.sp. Bickh [written] || RLW | SEM, 1986 [yellow label, printed-written] || Type [red label, written] || Zool. Mus. | Berlin [printed] || HOLOTYPUS | Saprinus | myrmecophilus | Bickhardt, 1910 | labelled by MNHUB 2004 [red label, printed]' (MFNB).

Saprinus carinipennis: HoLOTYPE: $q$, mounted on the tip of a triangular mounting point, four segments of left protarsus, two segments of right mesotarsus and four segments of both metatarsi missing, with the female genitalia placed in a small vial pinned under the specimen, 'MUSEum PARIS | MISIONES | Env. de San-Ignacio | Villa Lutecia | E.R Wagner 1910 [light-green label, printed] || SEPTEMBRE [printed] || JuIN [printed] || TYPE | unique [red label, printed-written] || Saprinus | carinipennis | n.sp. | H. Desbordes det. 1924 [printed-written]' (MNHN).

Platysaprinus zikani: SYNTYPES: glued onto rectangular mounting card, right antenna, left front leg and right metatibia missing, genitalia extracted and placed into a tiny vial under the specimen, ' $\delta$ [printed] $\|$ 

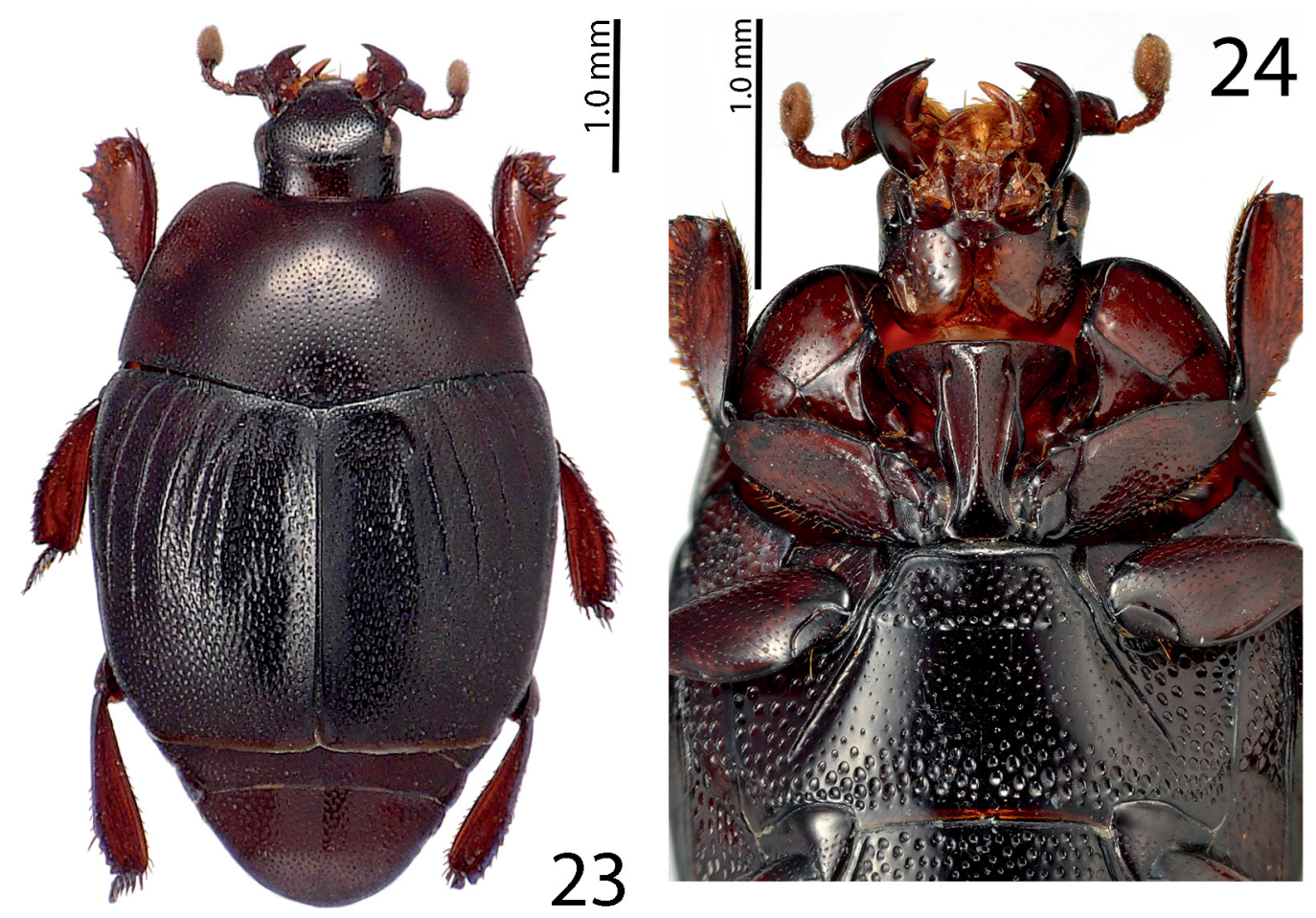

Figs 23-24. Euspilotus (Platysaprinus) myrmecophilus (Bickhardt, 1910). 23 -habitus, dorsal view (on the photo is the holotype of Saprinus carinipennis Desbordes, 1924); 24 - prosternum, meso- and metaventrite.

[rectangular mounting card with a glued specimen of Acromyrmex lundi] || Campo Bello | R. Jan. Zikán [written] || Acrom. | Lundi | Guér [written] || Platysaprinus | Zikáni | Reichsp. [written] || Platysapr. | Zikáni | Reichensp. [black-margined, written label] || Coll. Reichensperger | Paratyp ! [printed-written] || FICHADO [written]' (MACN); 1 spec., unknown sex, glued onto rectangular mounting card, right antennal club and right metatibia missing, with a specimen of Acromyrmex lundi glued onto a separate mounting card under the specimen, 'Acromyrm. | Lundi [written] || Est.Rio.Jan | Brasil [written] || Cotypus [light-green label, printed] || Platysaprinus | Zikani | Reichensp. [written] || Platysaprinus | Zikani n.sp. | Reichensp. [written] || FICHADO [written]' (MACN).

Platysaprinus zikani var. daguerrei: 3 SYNTYPES: sex unidentified, one of them lacking head, glued to the rectangular mounting cards, 'ROSAS - F.C. Sud | Provincia de Buenos Aires | JUAN B. DAGUERRE [printed] || con Acromyrmex | ambiguus Em. [written] || Typus [light-green label, printed] || Platysaprinus | Zikani Reichsp. | v. Daguerrei Bruch |C. BRUCH DETERM [printed-written]' (MACN).

Additional material examined. ARGENTINA: BuENos AIREs: 1 \&, 2 spec., with labels identical to those of Platysaprinus zikani var. daguerrei syntypes, but without any type labels (CVMD); Buenos Aires, 1930, 1 3, Daguerre (MSNG); Buenos Aires, Devoto, 24.vii.1928, 1 spec., S. J. Matúš lgt. (CVMD).

Redescription. Body (Fig. 23). PEL: 3.00-4.00 mm; APW: $1.30-1.70 \mathrm{~mm}$; PPW: $2.00-2.80 \mathrm{~mm}$; EW: 2.50-3.00 mm; EL: 2.00-3.00 mm; oblong-oval, slightly convex, cuticle castaneous, elytra darker, almost black. Body appendages reddish-brown.

Head. Frons broad, almost as broad as long, faintly depressed medially, densely punctate, punctures separated by about $0.5-1.0$ times their diameter; occipital stria complete; supra-orbital stria carinate, frontal stria widely interrupted, slightly continued on depressed epistoma, punctures on epistoma almost confluent. Mandibles apically acute, weakly punctate dorsally, punctation becoming denser laterally; subapical tooth on left mandible obtuse. Labrum weakly convex, finely punctate, labral pits adorned with two rather long labral setae. Rest of mouthparts not examined. Eyes slightly depressed, well visible from above; antennal scape thickened, on anterior face with two rather long setae, dorsally with 3-4 shorter amber setae; sensory structures of the antennal club not examined.

Pronotum (Fig. 23) slightly broader than long across median line, anterior angles obtuse; marginal pronotal stria laterally slightly carinate, complete, weakened behind head; pronotal disc wholly punctate, punctures separated by approximately 2-3 times their diameter, becoming larger and denser towards pronotal base. Pronotal hypomeron asetose.

Elytra (Fig. 23). Elytral epipleuron densely punctate, marginal epipleural stria thin, complete; marginal elytral stria carinate, complete, next to it a dense row of shallow punctures present, continues along elytral apex for short distance; apical elytral stria otherwise absent. Humeral elytral stria thin, present approximately on basal elytral fourth; inner subhumeral stria long, present as long fragment, basally almost connected to apex of humeral elytral stria, apically reaching approximately $4 / 5$ of elytral length. Elytral striae 1-2 deeply impressed, carinate, surpassing elytral half apically; striae 3-4 shorter, reaching approximately elytral half apically (in case of holotype of $S$. carinipennis impressed only as thin elongate bulges); basal ends of all striae hooked inwardly. In holotype of S. carinipennis (Fig. 23), next to fourth dorsal elytral stria conspicuous large elongate bulge present, elytral disc between it and elytral suture distinctly depressed, not observed in other specimens. Elytral suture of holotype of S. carinipennis 


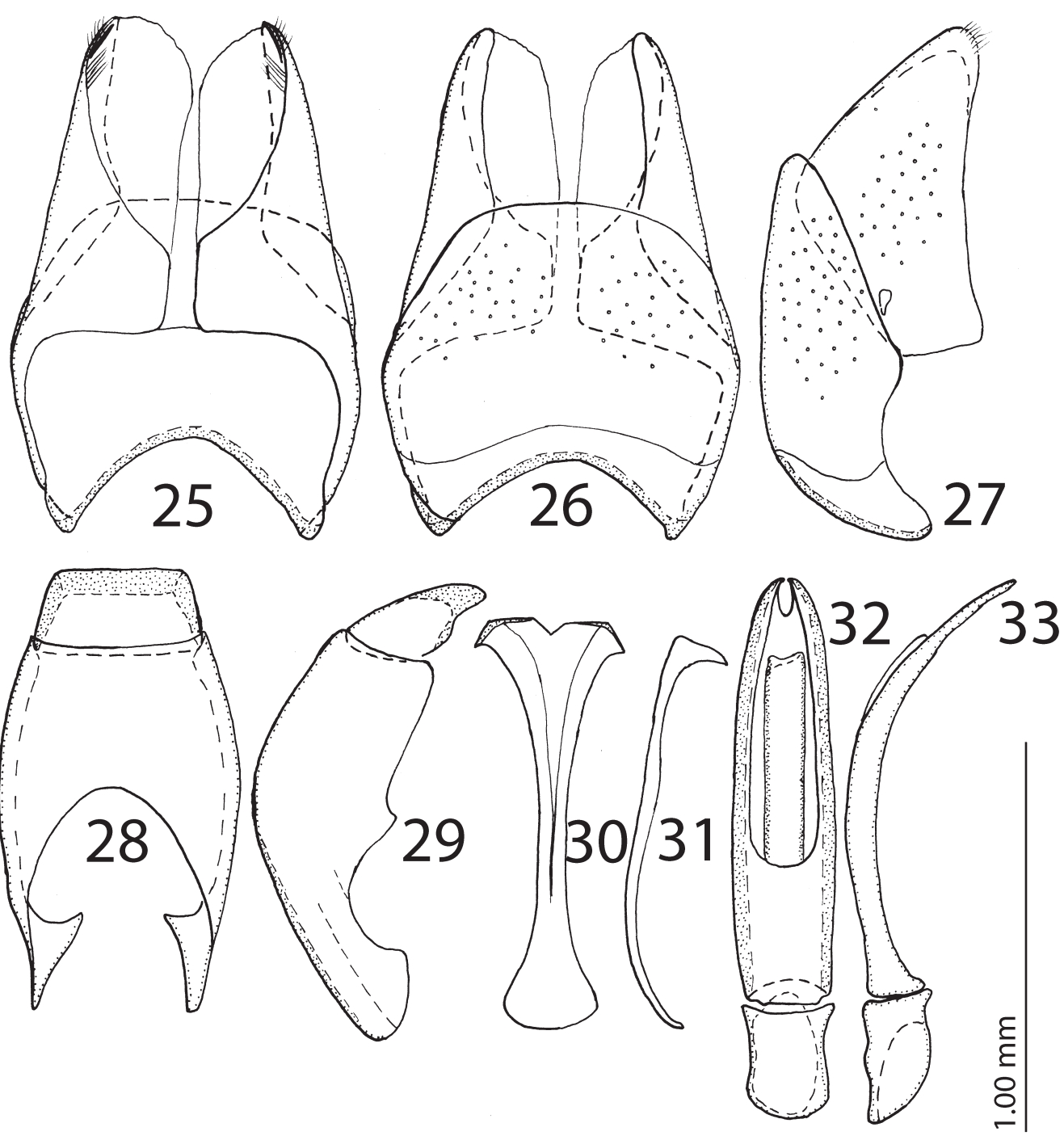

Figs 25-33. Male genitalia of Euspilotus (Platysaprinus) myrmecophilus (Bickhardt, 1910). 25 - VIII sternite and tergite, ventral view; 26 - ditto, dorsal view; 27 - ditto, lateral view; 28 - IX and X tergites, dorsal view; 29 - ditto, lateral view; 30 - IX sternite (spiculum gastrale), ventral view; 31 - ditto, lateral view; 32 - aedeagus, dorsal view; 33 - ditto, lateral view.

elevated (Fig. 23). Sutural elytral stria present as short weak fragment on apical elytral half, absent in holotype of S. carinipennis (Fig. 23). Entire elytral disc covered by very dense almost confluent shallow punctures separated by less than half their own diameter, extreme elytral apex impunctate.

Propygidium with punctation similar to that of elytra; pygidium with sparser punctation; punctures separated by approximately their own diameter, becoming sparser and finer towards apex; lateral sides of pygidium slightly elevated, but not costate as in $E$. (P.) latimanus.

Prosternum (Fig. 24). Outer lateral costa of prosternum not reaching prosternal process, interrupted by prosternal cavity. Prosternal process strongly compressed, keel-like, covered with sparse elongate punctures; apically with two prosternal foveae connected anteriorly by well-impressed marginal prosternal stria. Carinal prosternal striae well impressed, divergent apically and terminating in prosternal foveae. Lateral prosternal striae short, carinate, attaining carinal prosternal striae at their approximate apical 4/5.
Mesoventrite (Fig. 24). Marginal mesoventral stria complete; meso-metaventral stria absent, marked as row of large punctures in some specimens; disc of mesoventrite with punctures separated by their approximate diameter to twice their diameter.

Metaventrite (Fig. 24) with variously dense punctures separated by their own to several times their diameter, along basal third large shallow and densely-packed punctures appear; lateral metaventral stria straight, carinate, shortened apically, not reaching metacoxa. Lateral disc of metaventrite with large, deep punctures separated by twice to three times their diameters; metepisternum with similar, though denser punctures separated by less than their own diameter.

First visible abdominal ventrite along basal third with rather large and dense punctures becoming smaller and sparser apically; disc striate laterally.

Legs. Protibia dilated, outer margin with four low teeth topped by short denticle, followed by 6-7 short denticles; protibial spurt short, rather thin, growing out from near 
tarsal insertion; tarsal groove rather shallow; protibial stria complete, next to it another thinner stria parallel to it present. Setae of outer row short, regular. Outer part of posterior surface rugulose-lacunose; separated from smooth median part of posterior surface by thin and almost invisible stria; inner part of posterior surface smooth; posterior protibial stria complete, carinate.

Mesotibia dilated, outer margin with numerous short denticles, another row of closely set denticles present on anterior surface. Anterior surface of mesotibia faintly lacunose; anterior mesotibial stria complete. Metatibia dilated, similar to mesotibia.

Male genitalia. Overall of similar morphology to those of E. (P.) latimanus. Sternite VIII (Figs 25-26) widely separated medially; apex with large velum and brush of setae. Tergite VIII (Fig. 26) outwardly arcuate; sternite VIII and ventrite VIII not joined laterally (Fig. 27). Tergites IX and X (Figs 28-29) similar to those of $E$. (P.) latimanus; spiculum gastrale (Figs 30-31) as well. Aedeagus (Figs 32-33) stouter than with the preceding species, but generally similar to it.

Differential diagnosis. Differs from $E$. (P.) latimanus in the absence of the first dorsal elytral stria and the absence of a laterally costate propygidium. From $E$. (P.) ferreri sp. nov. differs in its entirely punctate elytra (basal half is impunctate in $E$. (P.) ferreri sp. nov.) and from $E$. (P.) vazdemelloi $\mathrm{sp}$. nov. differs in its broadly oval body and its basally not abbreviated dorsal elytral striae (abbreviated in $E$. (P.) vazdemelloi sp. nov.).

Biology. Collected in nests of Acromyrmex ambiguus (Emery, 1888) and A. lundi (Guérin-Méneville, 1838); an apparent inquiline .

Remarks. Arriagada (1987: 69) who examined the types of E. (P.) carinipennis, E. (P.) zikani and E. (P.) zikani var. daguerrei remarked that the type of $E$. $(P$.) carinipennis (Fig. 23) represents an unusual (teratological?) specimen differing from the rest by the elevated elytral suture, depressed fourth elytral interval, absent sutural elytral stria and presence of elongate bulge next to fourth dorsal elytral stria. All other morphological characters are identical with the rest of the examined specimens.

BICKHARDT (1910) explicitly mentioned that he had only one specimen of $S$. myrmecophilus. However, in the description he provided a length range of $31 / 2-4 \mathrm{~mm}$, which is presumably erroneous. DesBordes (1924) also explicitly mentioned only one specimen of $S$. carinipennis. Hence both are considered holotypes by monotypy.

Saprinus carinipennis Desbordes, 1924 was first transferred into Euspilotus (s. str.) by MAZUR (1987: 65), and further into the subgenus Platysaprinus by ARRIAGADA (1987: 68), although without formal statement in the publication. Saprinus myrmecophilus Bickhardt, 1910 was treated as 'Euspilotus incertae sedis' by MAZUR (1984, 1997, 2011).

BLACKWELDER (1944) erroneously listed this species twice in his catalogue, once in Euspilotus (on p. 178) and then in Saprinus (on p. 179).

Distribution. Known from Argentina, Brazil, and Uruguay (Fig. 56).

\section{Euspilotus (Platysaprinus) ferreri sp. nov. (Figs 34-44, 56)}

Type locality. Brazil: Minas Gerais, Parque National da Serra do Cipó. Type material examined. HoLOTYPE: , glued onto the tip of the mounting point, genitalia extracted and disarticulated, glued onto a separate mounting card under the specimen, 'Brazil Minas Gerais | P. N. Serra do Cipó | Campo Rupestre | 15 Octubre 2004 | Leg. Gustavo Schiffer [printed] || Euspilotus | (Platysaprinus) | ferreri | nov. sp. | Det. G. Arriagada, 2018 [printed] || Euspilotus (Platysaprinus) | ferreri sp. nov. | HOLOTYPE 2019 | des. T. Lackner \& G. |Arriagada [red label, written]' (CEMT). PARATyPes: $q$, 'BRASIL: Minas Gerais. | Mata do Paraíso. 2047’| S; 4251'W. F.Z.XII- | 1998 | Vaz de Mello [printed] || Euspilotus | (Platysaprinus) | ferreri | nov. sp. | Det. G. Arriagada, 2018 [printed] || Euspilotus (Platysaprinus) | ferreri sp. nov. | PARATYPE | des. T. Lackner \& G. | Arriagada 2019 [red label, written]'(CVMD); 今, 'BRASIL Minas Gerais | Viçosa | Noviembre 1999 | Leg. A. Bello [printed] || Euspilotus | (Platysaprinus) | ferreri | nov. sp. | Det. G. Arriagada, 2018 [printed] || Euspilotus (Platysaprinus) | ferreri sp. nov. | PARATYPE $\mid$ des. T. Lackner \& G. | Arriagada 2019 [red label, written]' (CTLA); †, 'BRASIL Río de Janeiro | Nova Friburgo | Marzo 2012 | Leg. E. Grossi [printed] || Euspilotus | (Platysaprinus) | ferreri| nov. sp. | Det. G. Arriagada, 2018 [printed] || Euspilotus (Platysaprinus) | ferreri sp. nov. | PARATYPE | des. T. Lackner \& G. | Arriagada 2019 [red label, written]' (CND); $\hat{\jmath}$, 'Brazil Mato Grosso | Lavras | Enero 2003 | leg. C. Cambraia [printed] || Euspilotus | (Platysaprinus) | ferreri | nov. sp. | Det. G. Arriagada, 2018 [printed] || Euspilotus (Platysaprinus) | ferreri sp. nov. | PARATYPE | des. T. Lackner \& G. | Arriagada 2019 [red label, written]' (MNHNC).

Description. Body (Fig. 34). PEL: 3.50-3.60 mm; APW: 1.40-1.50 mm; PPW: 2.50-2.75 mm; EW: 2.90-3.10 mm; EL: 2.10-2.20 mm; rectangular oval, dark brown; body appendages castaneous, antennal club lighter.

Head. Occipital stria well impressed, supra-orbital stria indistinct, frontal stria present in antero-lateral angles, for short distance prolonged onto epistoma. Frons with slight lateral and posterior depressions, wholly punctate, punctures separated by their own to twice their diameter; epistoma depressed, punctate. Eyes large, protruding. Labrum and mandibles similar to preceding species; other mouthparts not examined. Antennal scape dilated and thickened, with single long seta on anterior surface and single shorter seta dorsally. Antennal club circular, depressed dorso-ventrally, tomentose, without visible external sensory structures.

Pronotum (Fig. 34). Anterior pronotal angles obtuse, marginal pronotal stria complete, pronotum wholly punctate, punctures separated by $2-3$ times their diameter. Pronotal hypomeron asetose, scutellum small, triangular.

Elytra (Fig. 34). Elytral epipleuron weakly punctuate, marginal epipleural stria very thin; marginal elytral stria weakly cariniform, complete, continued along elytral apex for short distance; apical elytral stria otherwise absent. A dense row of prominent punctures present along marginal elytral stria. Inner subhumeral stria present as long median fragment, deeply impressed, with tiny punctures. Humeral elytral stria weakly impressed on basal elytral third; dorsal elytral striae well impressed, punctate, first longest, slightly surpassing elytral half apically, striae 2-4 slightly shorter, stopping short of half of elytral length apically, basal ends of all striae curved mediad. Fourth dorsal elytral stria curved inwardly and shortly continued as apical fragment of sutural elytral stria; sutural elytra stria otherwise present only as short and weak fragment on apical elytral half. 


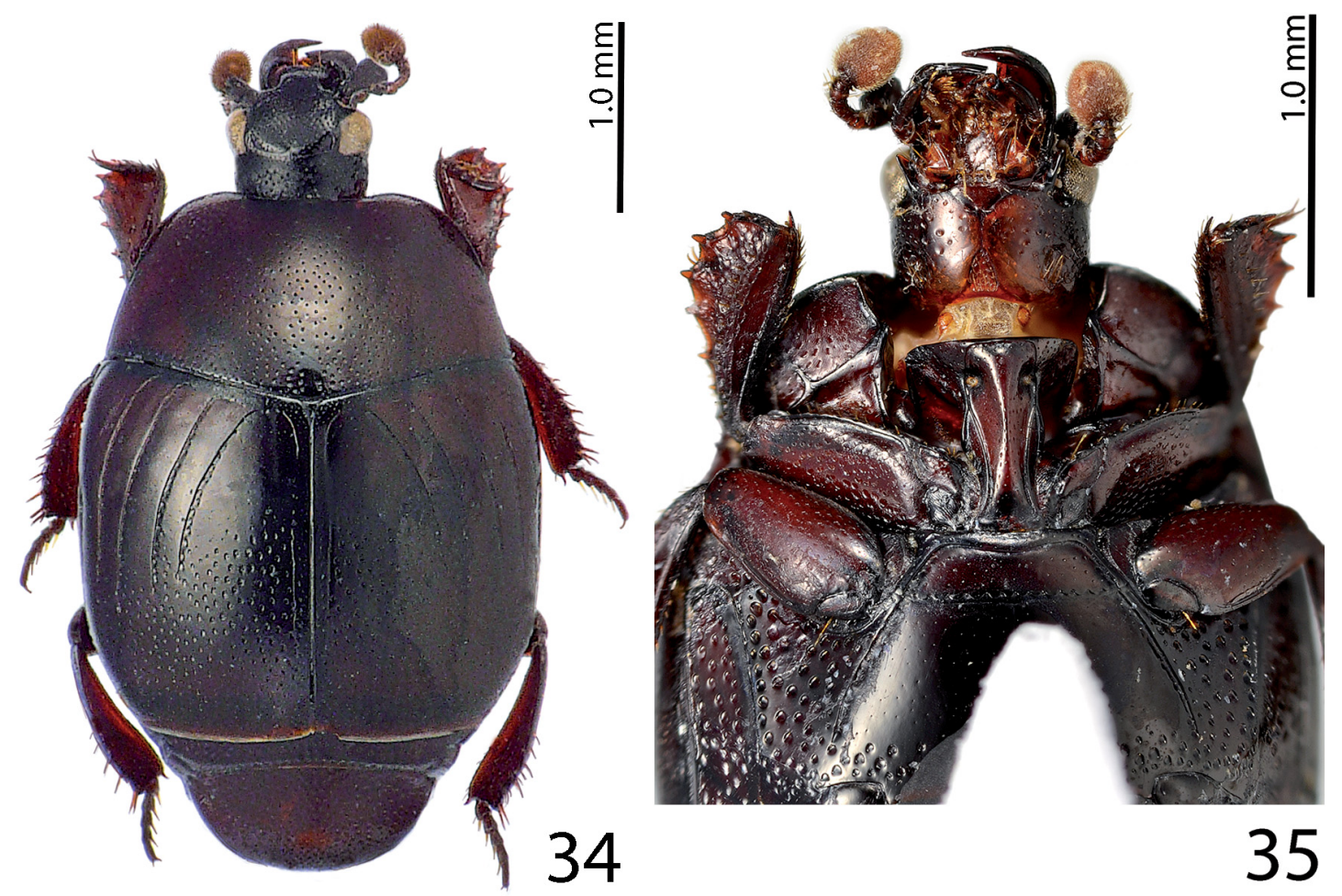

Figs 34-35. Euspilotus (Platysaprinus) ferreri sp. nov. 34 - habitus, dorsal view; 35 - prosternum, meso- and metaventrite.

Elytra wholly punctate, punctures on basal elytral half (chiefly among elytral striae) almost microscopic; on apical elytral half much denser and prominent, separated by once to twice their diameter, extreme elytral apex glabrous.

Propygidium and pygidium densely punctate, punctation of pygidium becoming finer and sparser apically; pygidium slightly depressed laterally.

Prosternum (Fig. 35). Prosternal process strongly compressed, keel-like, with fine scattered punctures; marginal prosternal stria present, terminating in large prosternal foveae; carinal prosternal striae divergent apically, terminating in prosternal foveae; lateral prosternal striae carinate, apically joining carinal striae at two-thirds point.

Mesoventrite (Fig. 35) approximately four times as wide as long, with scattered microscopic punctuation; marginal mesoventral stria complete, slightly carinate; meso-metaventral stria complete, undulate.

Metaventrite (Fig. 35). Disc of metaventrite with sparse microscopic punctation, along apical margin double row of larger punctures present; lateral metaventral stria almost complete, slightly carinate, stopping short of metacoxa. Lateral disc of metaventrite with three rows of large deep punctures.

Abdomen. First visible abdominal ventrite slightly depressed on basal third, almost completely striate laterally, disc along margins with larger punctures, medially only with sparse microscopic punctures.

Legs. Protibia dilated, on outer margin with 4-5 low teeth, each topped by short amber denticle, outer row of setae regular, protarsal groove shallow, protibial stria complete and carinate, median row of setae very short. Protibial spur short, growing out from apical protibial margin; outer part of posterior surface of protibia rugulose-lacunose; median part of posterior surface glabrous; posterior protibial stria complete, with microscopic setae; setae of inner protibial margin double, dense and regular. Mesotibia slightly dilated, on outer margin with six prominent denticles, outer row of setae sparse; median row of setae microscopic and scattered. Posterior mesotibial stria complete; protibial spur conspicuous. Anterior mesotibial stria complete; a single inner row of setae. Metatibia slightly dilated, on outer margin with seven denticles progressively increasing in length apically; metatibia otherwise similar to mesotibia.

Male genitalia. Sternite VIII (Figs 36-37) strongly sclerotized, separated medially, extreme apices with tuft of microscopic setae. Tergite VIII (Fig. 37) apically almost straight, not arcuate as in preceding species; sternite VIII and tergite VIII not fused laterally (Fig. 38). Tergite X (Fig. 39) apically inwardly arcuate; tergite IX (Fig. 39) somewhat more parallel-sided than in preceding species. Spiculum gastrale (Figs 41-42) dilated on both ends, its apex (= 'head') strongly sclerotized. Aedeagus (Figs 43-44) with slightly larger phallobase than with preceding species; ratio phallobase: parameres $1.0: 2.5$; otherwise similar to preceding species, strongly curved from lateral view, apex not as pointed as with preceding species.

Differential diagnosis. Differs from $E$. $(P$.) latimanus in the absence of costate first dorsal elytral stria as well as by the non-costate lateral pygidial margins. Differs from $E$. (P.) myrmecophilus in the impunctate basal third to half of the elytra, and from $E$. (P.) vazdemelloi sp. nov. in the broadly-oval body and basally non-abbreviated dorsal elytral striae 3-4 (abbreviated in case of $E$. (P.) vazdemelloi sp. nov.)). 


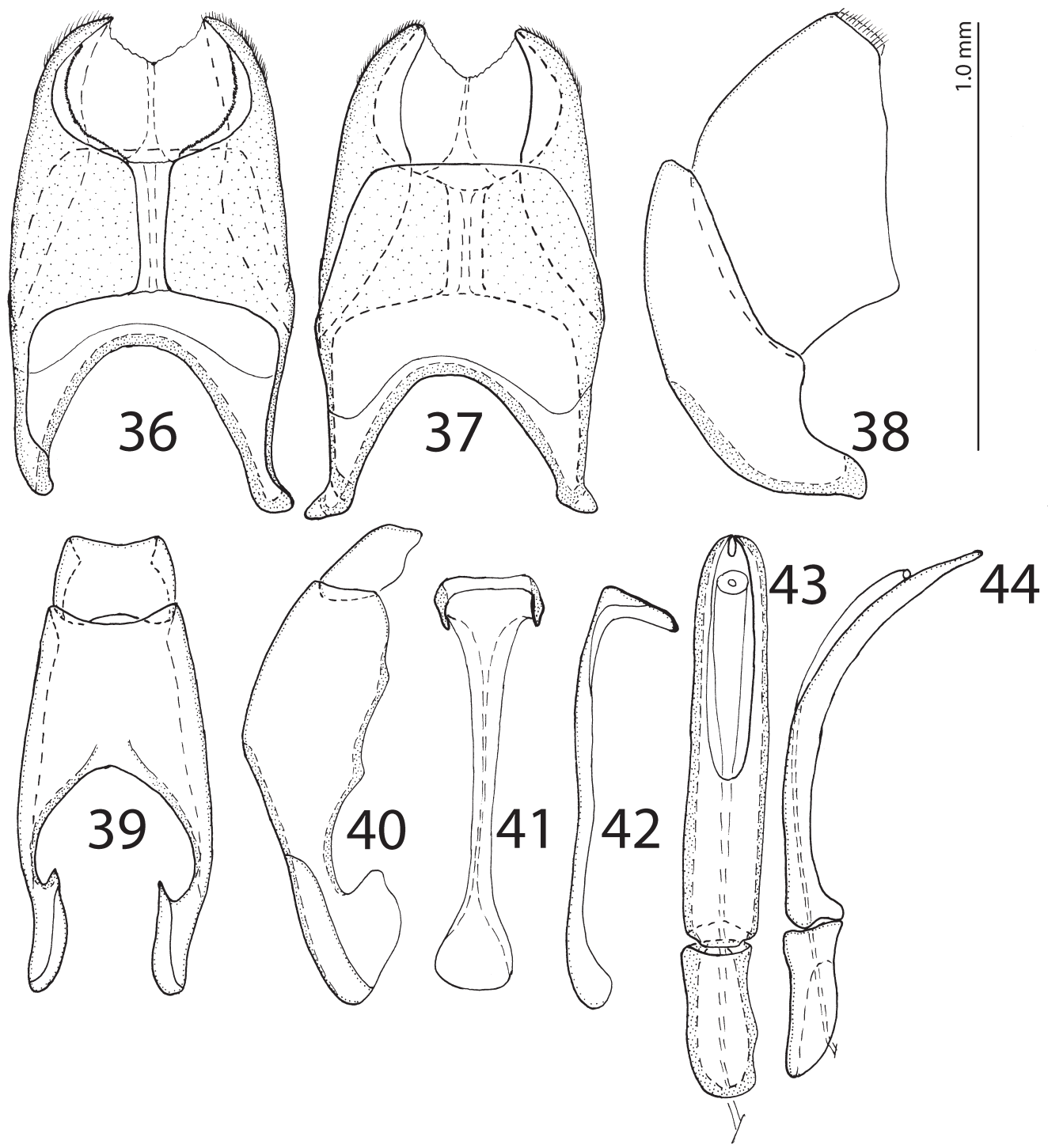

Figs 36-44. Male genitalia of Euspilotus (Platysaprinus) ferreri sp. nov. 36 - VIII sternite and tergite, ventral view; 37 - ditto, dorsal view; 38 - ditto, lateral view; 39 - IX and X tergites, dorsal view; 40 - ditto, lateral view; 41 - IX sternite (spiculum gastrale), ventral view; 42 - ditto, lateral view; 43 - aedeagus, dorsal view; 44 - ditto, lateral view.

Biology. Unknown.

Etymology. Patronymic, this new species is named after the Spanish entomologist Juan de Ferrer Andreu (19242008), a specialist on Histeridae.

Distribution. Known only from Brazil (Minas Gerais, Mato Grosso and Rio de Janeiro).

\section{Euspilotus (Platysaprinus) vazdemelloi sp. nov.} (Figs 45-55, 56)

Type locality. Brazil: Mato Grosso: Tangará da Serra.

Type material examined. HoLOTYPE: $\hat{\text {, }}$, with genitalia disarticulated and glued onto a separate mounting card under the specimen, 'Brasil Mato Grosso, Tangará | da Serra, Faz. Aparecida da | Serra, 14¹9'14"'S; 5743'50"W |637m. Cerrado, campo sujo. | FIT. 22/29.01.2009, leg. R.J. Silva [printed] || Euspilotus | (Platysaprinus)| vazdemelloi | nov. sp. | Det. G. Arriagada, 2018 [printed] || Euspilotus (Platysaprinus) | vazdemelloi sp. nov. | HOLOTYPE | des. T. Lackner \& G. |Arriagada 2019 [red label, written]' (CEMT). PARATYPES: $2 \hat{\jmath}$, with labels identical to the holotype (one in CTLA, one in CVMD).

Description. Body (Fig. 45). PEL: 2.10-2.30 mm; APW: 0.80-1.00 mm; PPW: $1.50-1.70 \mathrm{~mm}$; EW: $1.70-1.80 \mathrm{~mm}$;
EL: $1.50-1.60 \mathrm{~mm}$. Body elongate oval, cuticle chestnut brown, appendages light-brown, antennal club and maxillae lighter, amber-coloured.

Head. Occipital stria present, supra-orbital stria indistinguishable, frontal stria widely interrupted medially, prolonged onto depressed epistoma. Entire frontal disc as well as epistoma densely punctate, punctures separated by a distance equal to their own to twice their diameter. Antennal scape thickened and dilated, dorsally with two thick prominent setae; anterior surface likewise with two similar setae; sensory structures of antennal club not examined. Eyes flattened, but visible from above. Mandibles with sparse microscopic punctures, apex acute, sub-apical tooth on left mandible indiscernible; labrum with two labral setae; rest of mouthparts not examined.

Pronotum (Fig. 45). Marginal pronotal stria complete, strongly carinate laterally; apical pronotal angles prominent; pronotal disc wholly punctate, laterally punctures larger, separated by about twice their diameter, medially punctures sparser, almost microscopic, separated by 

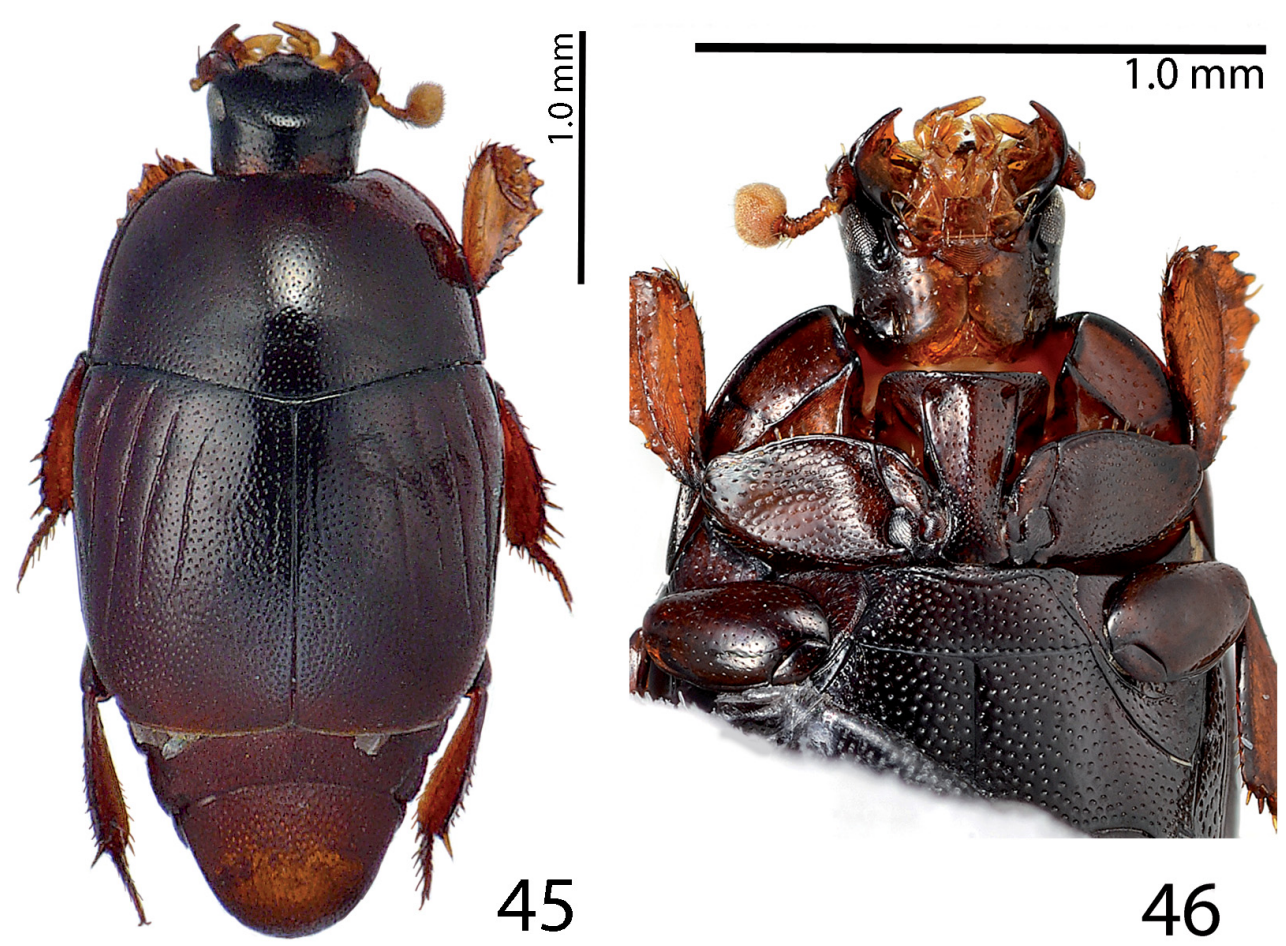

Figs 45-46. Euspilotus (Platysaprinus) vazdemelloi sp. nov. 45 - habitus, dorsal view; 46 - prosternum, meso- and metaventrite.
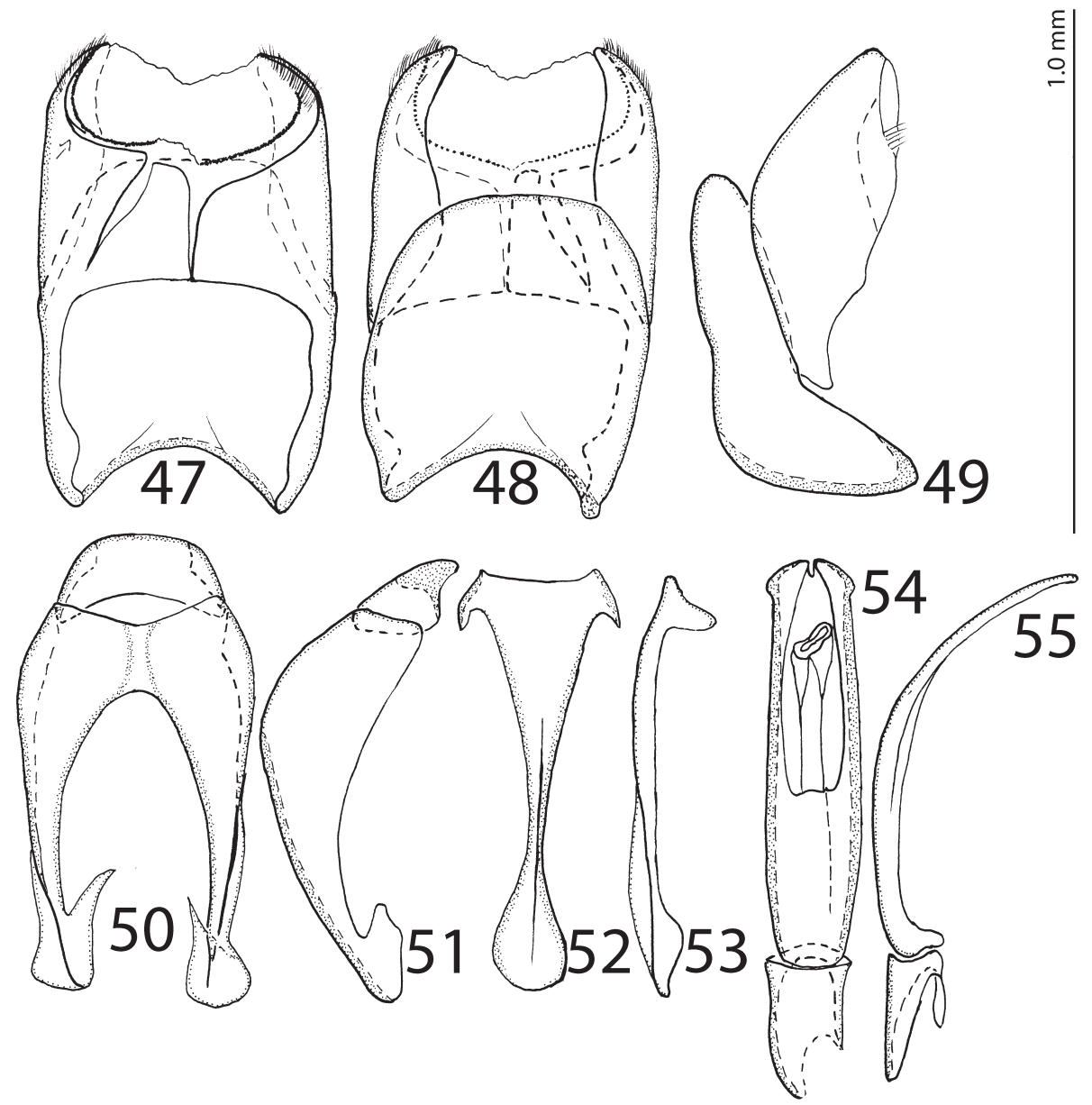

Figs 47-55. Male genitalia of Euspilotus (Platysaprinus) vazdemelloi sp. nov. 47 - VIII sternite and tergite, ventral view; 48 - ditto, dorsal view; 49 ditto, lateral view; 50 - IX and X tergites, dorsal view; 51 - ditto, lateral view; 52 - IX sternite (spiculum gastrale), ventral view; 53 - ditto, lateral view; 54 - aedeagus, dorsal view; 55 - ditto, lateral view. 
several times their diameter. Pronotal hypomeron asetose, scutellum small, triangular.

Elytra (Fig. 45). Elytral epipleuron almost impunctate, marginal epipleural stria fine, complete; marginal elytral stria complete and strongly carinate, continuing along elytral apex for short distance as weakened apical elytral stria. Humeral elytral stria present as short weakened fragment on basal elytral third; inner subhumeral stria present as short fragment on apical elytral half; elytral striae 1-4 deeply impressed, striae 1-2 reaching approximately $3 / 4$ of elytral length apically, striae 3-4 shorter, slightly surpassing elytral half, shortened also basally. Basal ends of elytral striae (except for fourth stria) not hooked inwardly; fourth elytral stria vaguely hooked towards indistinct sutural elytral stria, which is present only as row of punctures, reaching approximately elytral half apically. Entire elytral disc densely punctate, punctures separated by a distance equal their own length to less than half their diameter; punctures on basal elytral fifth and in inter-strial interspaces much finer and sparser, separated by several times their diameter.

Propygidium and pygidium. Propygidium with deep confluent punctures; pygidium on basal half with very dense deep punctures, separated by less than half their diameter, on apical half punctures becoming finer and sparser, separated by several times their diameter.

Prosternum (Fig. 46). Prosternal process compressed, marginal prosternal stria well impressed, connected with widely divergent carinal prosternal striae; lateral prosternal striae indistinct, present as very short basal fragment. Prosternal foveae present; disc of prosternal process densely punctate.

Mesoventrite (Fig. 46) approximately three times as wide as long, wholly densely punctate, marginal mesoventral stria complete; meso-metaventral stria vague, present as row of punctures.

Metaventrite (Fig. 46). Lateral metaventral stria complete, curved outwardly and apically reaching metepisternum. Entire metaventrite densely punctate, punctures separated by their own to approximately twice their diameter. Metepisternum with dense ovoid punctures; marginal metepisternal stria present, in punctures within stria.

First visible abdominal ventrite densely punctate, punctures becoming sparser and finer medially, laterally completely striate.

Legs. Outer margin of protibia with four low triangular teeth topped by short amber denticle, followed by two short microscopic denticles; protibial spur short, growing out from apical protibial margin; protibia strongly dilated; protarsal groove shallow; protibial stria complete; setae of outer row regular, short and widely spaced; setae of median row indiscernible. Posterior surface of protibia with scattered punctures; outer part of posterior surface separated from median part by row of punctures; posterior protibial stria indistinct, in sparse punctures within stria. Mesotibia dilated, on outer margin with five widely spaced denticles; metatibia dilated, but narrower than mesotibia, outer margin with three very short widely spaced denticles, near tarsal insertion two longer denticles present.
Male genitalia. Sternite VIII (Figs 47-48) almost parallel-sided, medially not fused, apex with tuft of dense setae. Tergite VIII (Fig. 48) outwardly arcuate, rather short; sternite VIII and tergite VIII not fused laterally (Fig. 49). Tergite IX (Figs 50-51) apically rather thin; tergite X (Fig. 50) basally inwardly arcuate, rather small. Spiculum gastrale (Figs 52-53) gradually dilated medio-apically, its 'head' significantly larger than its 'tail'. Aedeagus (Figs 54-55) almost parallel-sided, basal piece smaller than in preceding species, length of phallobase : length of parameres approximately $1: 4$; strongly curved from lateral view. Differential diagnosis. Euspilotus (Platysaprinus) vazdemelloi sp. nov. differs from the three previous species in its smaller size, elongate-oval body, near-absence of sutural elytral striae, and, particularly by the basally abbreviated third and fourth dorsal elytral striae.

Biology. Unknown, specimens were collected by flight interception traps.

Etymology. Patronymic, the new species is named after the Brazilian entomologist, Fernando Zagury Vaz-de-Mello, from the Mato Grosso Federal University (Cuiabá).

Distribution. Known only from Brazil (Mato Grosso).

Remarks. Euspilotus (Platysaprinus) vazdemelloi sp. nov. is undoubtedly the most distinctive species of the subgenus, and we admit that its inclusion here is only tentative.

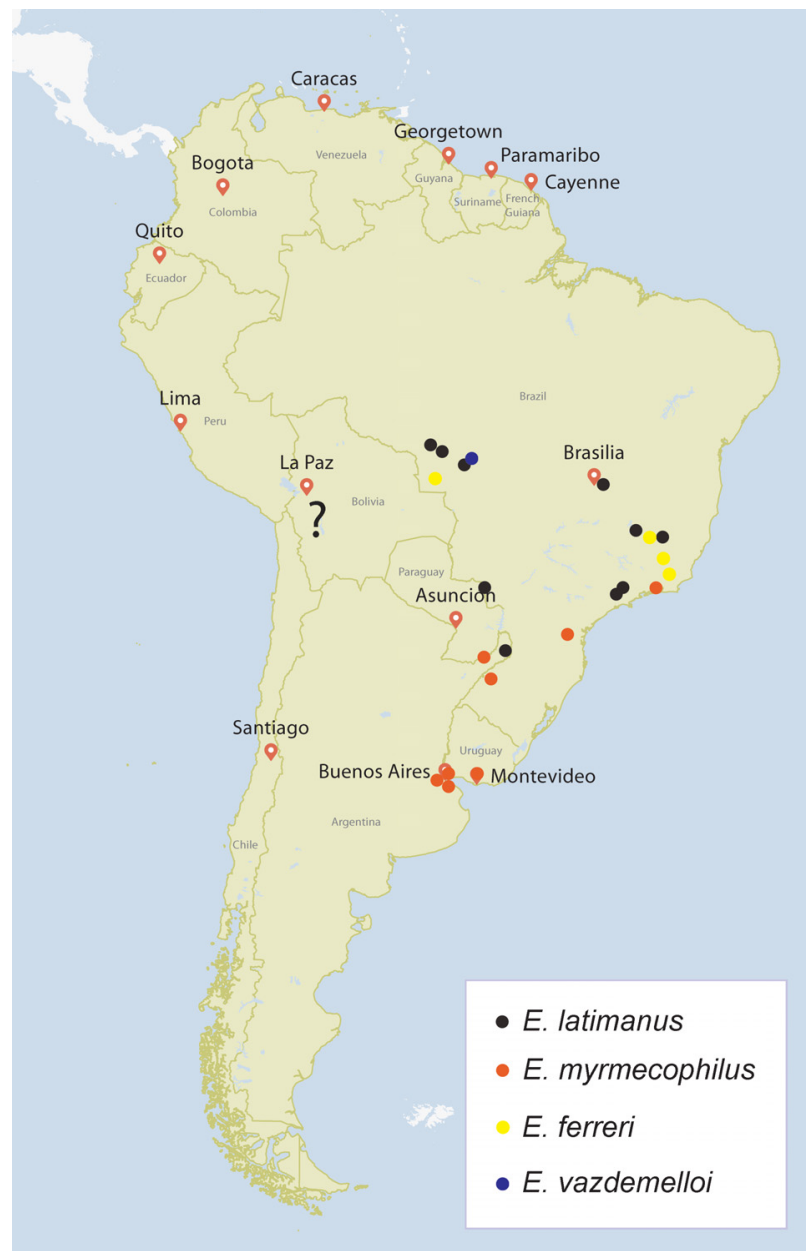

Fig. 56. Distributional map of the subgenus Platysaprinus Bickhardt, 1916 of the genus Euspilotus, 1907. 


\section{Discussion}

The strictly Neotropical subgenus Platysaprinus of the genus Euspilotus currently contains four species, two of which are newly described here. The four species are characterized by non-metallic, dark-brown, usually wholly punctate cuticle of the dorsum, with a widely interrupted frontal stria, and, especially, dilated and shortened tibiae as well as triangularly dilated antennal scape, among other characteristics, which are common to other members of $E u$ spilotus. As mentioned in the introduction, it is complicated and perhaps premature to divide the genus Euspilotus into subgenera, especially in light of more than 40 new species, which the junior author (G. A.) is currently describing. Within the genus, we observe great morphological diversity, making the subgeneric limits dubious. Therefore our paper does not strive to give the final answer to the subgeneric synapomorphies of Platysaprinus, as we admit that the validity of the subgenera needs to be tested by rigorous phylogenetic methods. Indeed, we include the new species $E$. $(P$.) vazdemelloi sp. nov. into the subgenus only tentatively, since it apparently does not fit into any other subgenera of Euspilotus, and seems to be most similar to the members of Platysaprinus. Although the ecological niches of the two newly described species are unknown at present, we presume that based on their external morphologies, they will be inquilines of social insects or perhaps ground-dwelling rodents. We hope that our paper provides the necessary framework for further studies on the rich and largely unexplored histerid fauna of South America.

\section{Acknowledgements}

We would like to thank all curators of the aforementioned collections for the loan of the specimens. We also thank Arturo Roig (Buenos Aires, Argentina), Alfred Newton (Chicago, USA), Sławomir Mazur (Warsaw, Poland) and Alexey K. Tishechkin (Sacramento, USA) for their help with literature. We are indebted to the wife of the senior author Pepina Artimová, for her help with the Adobe Illustrator drawins. Special thanks to the two anonymous reviewers for their critical suggestions, which increased the quality of our paper.

\section{References}

ARRIAGADA G. 1987: Notas sininimicas y datos distribucionales de Saprininae neotropicales. Revista Chilena de Entomologia 15: 61-70. ARRIAGADA G. 2015: Nueva especie de Saprininae de Perú, Chile y Argentina, nuevos registros y sinonimias (Coleoptera: Histeridae).
Boletín del Museo Nacional de Historia Natural, Chile 64: 181-197. ARRIAGADA G., JOFRÉ F. N. \& ABALLAY F. H. 2019: Nueva especie de Euspilotus Lewis de Argentina (Coleoptera: Histeridae). Revista del Museo Argentino de Ciencias Naturales, Nueva Série 21: 7-15.

BICKHARDT H. 1910: Beiträge zur Kenntnis der Histeriden V. Entomologische Blätter 6: 223-227.

BICKHARDT H. 1914: Das System der Histeriden (Vorläufige Mitteilung). (22. Beitrag zur Kenntnis der Histeriden). Entomologische Blätter 10: 305-308.

BICKHARDT H. 1916-1917: Histeridae. In: WYTSMAN P. (ed.): Genera Insectorum. Fascicule 166a, 166b. Martinus Nijhoff, La Haye, 302 pp. +15 pls.

BLACKWELDER R. E. 1944: Checklist of the coleopterous insects of Mexico, Central America, the West Indies, and South America. Part 1. United States National Museum Bulletin 185: i-xii + 1-188.

BRUCH C. 1931: Algunos mirmecófilos y termitófilos nuevos y poco conocidos de la Argentina. Revista de Entomologia 1: 387-395.

DÉGALLIER N., ARRIAGADA G., CATERINO M. S., KANAAR P., MOURA D. P., TISHECHKIN A. K. \& WARNER W. B. 2012: Coleoptera Histeridae de Guyane. VII. Compléments au catalogue avec des données sur la faune du Surinam et une contribution à la connaissance des Saprininae. Pp. 33-52. In: TOUROULT J. (ed.): Contribution à l'étude des Coléoptères de Guyane Tome VI. Supplément au Bulletin 'Le Coléoptériste', ACOREP, Paris, 88 pp.

DESBORDES H. 1924: Description d'un Saprinus nouveau de l'Amérique du Sud (Col. Histeridae). Bulletin du Muséum National d'Histoire Naturelle 30: 372-373.

LACKNER T. 2010: Review of the Palaearctic genera of Saprininae (Coleoptera: Histeridae). Acta Entomologica Musei Nationalis Pragae 50 (Supplementum): 1-254.

LACKNER T. 2014: Phylogeny of the Saprininae reveals interesting ecological shifts in the history of the subfamily (Coleoptera: Histeridae). Zoological Journal of the Linnean Society 172: 521-555.

LACKNER T., MAZUR S. \& NEWTON A. F. 2015: Family Histeridae. Pp. 76-130. In: LÖBL I. \& LÖBL D. (eds): Catalogue of Palaearctic Coleoptera. Vol. 2. Hydrophiloidea-Staphylinoidea, part 1. Revised and updated edition. Brill, Leiden \& Boston, $1702 \mathrm{pp}$.

LEWIS G. 1907: On a new species of Histeridae and notices of others. Annals and Magazine of Natural History, Series 7 20: 480-484.

MAZUR S. 1984: A world catalogue of Histeridae. Polskie Pismo Entomologiczne 54: 1-376.

MAZUR S. 1997: A world catalogue of the Histeridae (Coleoptera: Histeridae). Genus Supplement 7: 1-373.

MAZUR S. 2011: A concise catalogue of the Histeridae (Insecta: Coleoptera). Warsaw University of Life Sciences - SGGW Press, Warsaw, $332 \mathrm{pp}$.

ÔHARA M. 1994: A revision of the superfamily Histeroidea of Japan (Coleoptera). Insecta Matsumurana, New Series 51: 1-238.

REICHENSPERGER A. 1926: Neue Beiträge zur Artenkenntnis und zur Lebensweise myrmekophiler Histeriden. Verhandlungen der III International Kongress der Entomologie, Zürich 2[1925]: 184-203.

SCHMIDT A. 1890: Neue Histeriden (Coleoptera). Entomologische Nachrichten 4: 50-51.

TISHECHKIN A. K. 2007: Phylogenetic revision of the genus Mesynodites (Coleoptera: Histeridae: Hetaerinae) with descriptions of new tribes, genera and species. Sociobiology 49: 1-167. 
